\title{
Prognostic significance of combined pretreatment body mass index (BMI) and BMI loss in patients with esophageal cancer
}

This article was published in the following Dove Press journal: Cancer Management and Research

\author{
Wen-Shen $\mathrm{Gu}^{1,2, *}$ \\ Wei-Zhen Fang ${ }^{1,2, *}$ \\ Chun-Yue Liu ${ }^{1,2}$ \\ Kun-Yi Pan ${ }^{1,2}$ \\ Rui Ding ${ }^{1,2}$ \\ Xiao-Hui $\mathrm{Li}^{3}$ \\ Chao-Hui Duan ${ }^{1,2}$ \\ 'Guangdong Provincial Key Laboratory of \\ Malignant Tumor Epigenetics and Gene \\ Regulation, Sun Yat-Sen Memorial \\ Hospital, Sun Yat-Sen University, \\ Guangzhou 510120, People's Republic of \\ China; ${ }^{2}$ Department of Laboratory \\ Medicine, Sun Yat-Sen Memorial Hospital, \\ Guangzhou 5I0I20, People's Republic of \\ China; ${ }^{3}$ Key Laboratory of Oncology in \\ South China, Collaborative Innovation \\ Center for Cancer Medicine, \\ Department of Clinical Laboratory \\ Medicine, Sun Yat-Sen University Cancer \\ Center, Guangzhou 510060, People's \\ Republic of China
}

*These authors contributed equally to this work
Correspondence: Chao-Hui Duan Guangdong Provincial Key Laboratory of Malignant Tumor Epigenetics and Gene Regulation, Sun Yat-Sen Memorial Hospital, Sun Yat-Sen University, No. 107 Yanjiang West Road, Guangzhou, People's Republic of China

Tel +86208 I332072

Fax +862081332072

Email1725012289@qq.com
Background: Body mass index (BMI) has been associated with a risk of esophageal cancer. However, the influence of BMI and BMI loss on people with esophageal cancer that were treated with different therapies has not been described in China.

Methods: In total, 615 consecutive patients that underwent esophagectomy and/or chemotherapy/radiotherapy were classified according to the Asian-specific BMI ( $\left.\mathrm{kg} / \mathrm{m}^{2}\right)$ cutoff values. The impact of BMI and BMI loss on long-term overall survival (OS) was estimated using the Kaplan-Meier method and Cox proportional hazard models.

Results: Multivariate analysis showed that overweight and obese patients had a more favorable survival than normal weight and underweight patients $(p=0.017)$. Patients with a low BMI and high BMI loss before therapy had worse OS than others $(p=0.001)$. Subgroup analysis showed that patients with a high BMI were more likely to suffer hypertension $(p<0.001)$ and receive only surgery $(p<0.001)$, and they were less likely to be smokers $(p=0.007)$ and anemic $(p<0.001)$. Conversely, patients with high BMI loss were more likely to be anemic $(p=0.001)$, to have advanced pathological stage $(p=0.012)$, and to receive chemotherapy and radiotherapy $(p=0.001)$. Moreover, the mortality rate was higher when patients had a high BMI loss. There is no survival benefit of higher BMI in the non-esophageal squamous cell carcinoma (ESCC) group. Conclusion: Pretreatment BMI was an independent prognostic factor for long-term survival in esophageal cancer patients treated with different treatments. The overall survival was increased in esophageal cancer patients with a high pretreatment BMI and no BMI loss. There is no survival benefit of higher BMI in the non-ESCC group.

Keywords: BMI, BMI loss, esophageal cancer, long-term survival

\section{Introduction}

Esophageal cancer is one of the most common digestive system malignancies in the world. It is especially prevalent in some Asian countries, and about half of the cases occur in China. ${ }^{1-3}$ With the advancements in surgical techniques and therapy, the outcomes of esophageal cancer have improved, but the long-term survival rate is still unsatisfactory. $^{1,3,4}$ A common presenting symptom of esophageal cancer is weight loss. ${ }^{5,6}$ This is because most patients will experience dysphagia, which leads to reduced food intake. ${ }^{7}$ Moreover, increased energy consumption is induced by the tumor, which can also contribute to weight loss. ${ }^{8}$ Considerable weight loss in cancer patients is a risk factor for long-term survival. Many studies have indicated that excessive postoperative or post-diagnostic weight loss leads to worse long-term outcomes in many cancers, ${ }^{9-11}$ including esophageal cancer. ${ }^{12,13}$ Furthermore, several studies have demonstrated that 
a high body mass index (BMI) is a well-recognized risk factor for esophageal cancer. ${ }^{12,14-16}$ However, these studies were primarily concerned with the western population and patients who had undergone surgical tumor resection. Thus far, the impact of both BMI and a reduction in BMI prior to therapy on the long-term survival in Chinese esophageal cancer patients treated with adjuvant therapy, including chemotherapy and/or radiotherapy, has not been explored. Therefore, the aim of this study was to evaluate the impact of BMI and BMI loss prior to therapy on long-term survival in esophageal cancer patients treated with various types of therapy.

\section{Patients and methods}

\section{Patients}

We identified consecutive patients with esophageal cancer at the Sun Yat-sen University Cancer Center. Based on our previous study, ${ }^{17}$ patients with esophageal squamous cell carcinoma (ESCC) were identified between May 2007 and December 2008. Patients with non-ESCC were identified between and March 2006 and September 2016 because of low incidence (Table S1). Follow-up time was calculated from the date of surgery to the event or date of the last contact. Follow-up continued until July 2018. The endpoint was overall survival (OS). OS was calculated from the time of surgery to the time of death from any causes or the date of the last follow-up, if the patients were still alive. Patients were excluded if their BMI was unknown or if they had a history of other cancers. Patient characteristics were collected from retrospective medical record reviews using a standardized data collection form. The most common surgical approaches included the left transthoracic procedure, the Ivor-Lewis approach, and the cervicothoracoabdominal procedure. Pathologic stage was determined according to the 7 th edition AJCC staging system. ${ }^{18}$ The study was approved by the Ethics Committee of the Sun Yat-sen University Cancer Center and patient consent to review their medical records was not required for the research project did not involve personal privacy and commercial interests. Patient information would be kept strictly confidential and in compliance with the Helsinki declaration.

\section{$\mathrm{BMI}$ value and $\mathrm{BMI}$ loss group}

BMI $\left(\mathrm{kg} / \mathrm{m}^{2}\right)$ was calculated based on a direct measurement of height and weight at diagnosis. Patients were classified according to the Asian-specific BMI cutoff value of the Chinese population. ${ }^{19}$ The three categories were as follows: underweight $\left(<18.5 \mathrm{~kg} / \mathrm{m}^{2}\right)$, normal weight $\left(18.5-22.9 \mathrm{~kg} / \mathrm{m}^{2}\right)$, and overweight and obese $\left(\geq 23.0 \mathrm{~kg} / \mathrm{m}^{2}\right)$. BMI loss was calculated based on height and weight loss compared to their weight at diagnosis. BMI loss was divided into the following three groups: group 1 (no BMI loss), group 2 (BMI loss $\leq 2$ ), group 3 (BMI loss $>2$ ) refer to some researches. ${ }^{13,20,21}$

\section{Statistical analysis}

Statistical analysis was performed using the SPSS 19.0 for Windows software system (SPSS Inc., Chicago, IL, USA). Differences between the three groups were tested by the Kruskal-Wallis test. The associations between BMI categories and clinicopathologic parameters were analyzed by the $\chi^{2}$-square test or Fisher's exact test. Survival curves were calculated by the Kaplan-Meier method and analyzed by the log-rank test. Multivariable analysis was performed using Cox's proportional hazards regression model using the enter procedure (the entry and removal probabilities were 0.05 and 0.10 , respectively). $p$-values $<0.05$ were regarded as statistically significant.

\section{Results}

\section{Baseline characteristics by $\mathrm{BMI}$ and $\mathrm{BMI}$ loss}

There were 615 patients pathologically confirmed with esophageal cancer enrolled in this study. Of them, 474 (77.1\%) were men, and $141(22.9 \%)$ were women. All patients were between 23-82 years of age, with a median age of 59 years. The characteristics and parameters of the patients are listed in Tables 1 and 2. Patients with a high BMI were more likely to be diagnosed with hypertension $(p<0.001)$ and less likely to be smokers $(p=0.007)$ or anemic $(p<0.001)$. Furthermore, overweight and obese patients were less likely to require adjuvant therapy in addition to their operation $(p<0.001)$. On the contrary, patients with high BMI loss were more likely to receive chemotherapy and radiotherapy $(p=0.001)$. Moreover, BMI and BMI loss demonstrated a positive correlation with the cancer stage. Patients with high BMI loss and a low BMI had higher values for $\mathrm{T}(p=0.007)$ classification and lymph node metastasis $(p<0.001)$ (Table S2). There were no significant differences in histopathology, gender, age, alcohol history, diabetes mellitus, family history, and cancer location.

\section{Univariate and multivariate analysis}

The median OS of the entire cohort was 31.0 months, and it ranged from 1.0-144.0 months. At the end of the observation period, 61.1\% (376/615) of patients had died due to diseaserelated or unrelated factors (Table 3 ). To evaluate the prognostic 
Table I Relationship between the BMI and the clinical characteristics in 615 patients with esophageal cancer

\begin{tabular}{|c|c|c|c|c|c|}
\hline \multirow[t]{2}{*}{ Characteristics } & \multirow[t]{2}{*}{ Overall $(n=6 \mid 5)$} & \multicolumn{3}{|l|}{ BMI } & \multirow[t]{2}{*}{$p$-value } \\
\hline & & $<18.5(\%)(n=88)$ & $18.5-22.9(\%)(n=307)$ & $\geq 23.0(\%)(n=220)$ & \\
\hline \multicolumn{6}{|l|}{ Histopathology } \\
\hline ESCC & $446(72.5)$ & $65(73.9)$ & $225(73.3)$ & $156(70.9)$ & 0.828 \\
\hline Non-ESCC & $169(27.5)$ & $23(26.1)$ & $82(26.7)$ & $64(29.1)$ & \\
\hline Small cell carcinoma & $63(37.3)$ & $5(21.7)$ & $31(37.8)$ & $27(42.2)$ & 0.638 \\
\hline Adenocarcinoma & $46(27.2)$ & $2(8.7)$ & $21(25.6)$ & $23(35.9)$ & \\
\hline \multicolumn{6}{|l|}{ Gender } \\
\hline Male & $474(77.1)$ & $62(70.5)$ & $240(78.2)$ & $172(78.2)$ & 0.280 \\
\hline Female & $|4|(22.9)$ & $26(29.5)$ & $67(21.8)$ & $48(21.8)$ & \\
\hline \multicolumn{6}{|l|}{ Age (years) } \\
\hline$\leq 59$ years & $3 \mid 4(5||)$. & $54(61.4)$ & |47(47.9) & $\mid I 3(5 \mid .4)$ & 0.083 \\
\hline$>59$ years & $30 I(48.9)$ & $34(38.6)$ & $160(52.1)$ & $107(48.6)$ & \\
\hline \multicolumn{6}{|l|}{ Alcohol } \\
\hline Never & $375(62.0)$ & $50(56.8)$ & I77(57.7) & $148(67.3)$ & 0.057 \\
\hline Ever & $240(38.0)$ & $38(43.2)$ & $130(42.3)$ & $72(32.7)$ & \\
\hline \multicolumn{6}{|l|}{ Smoking } \\
\hline Never & $217(35.3)$ & $24(27.3)$ & $98(31.9)$ & $95(43.2)$ & 0.007 \\
\hline Ever & $398(64.7)$ & $64(72.7)$ & $209(68.1)$ & $125(56.8)$ & \\
\hline \multicolumn{6}{|l|}{ Diabetes mellitus } \\
\hline No & $587(95.4)$ & $85(96.6)$ & 293(95.4) & $209(95.0)$ & 0.833 \\
\hline Yes & $28(4.6)$ & $3(3.4)$ & $14(4.6)$ & II (5.0) & \\
\hline \multicolumn{6}{|l|}{ Hypertension } \\
\hline No & $453(73.7)$ & $81(92.0)$ & $235(76.5)$ & $137(62.3)$ & 0.000 \\
\hline Yes & $162(26.3)$ & $7(8.0)$ & $72(23.5)$ & $83(37.7)$ & \\
\hline \multicolumn{6}{|l|}{ Anemia } \\
\hline No & $548(89.1)$ & $68(77.3)$ & $273(88.9)$ & 207(94.I) & 0.000 \\
\hline Yes & $67(11.9)$ & $20(22.7)$ & $34(I I .1)$ & $13(5.9)$ & \\
\hline \multicolumn{6}{|l|}{ Family history } \\
\hline No & $499(81.1)$ & $72(81.8)$ & $259(84.4)$ & $168(76.4)$ & 0.067 \\
\hline Yes & $116(19.9)$ & $16(18.2)$ & $48(15.6)$ & $52(23.6)$ & \\
\hline \multicolumn{6}{|l|}{ Location } \\
\hline Up & $56(9.1)$ & $7(8.0)$ & $31(10.1)$ & $18(8.2)$ & 0.938 \\
\hline Middle & $380(61.8)$ & $55(62.5)$ & $189(6 \mid .6)$ & $\mid 36(6 \mid .8)$ & \\
\hline Low & $179(29.1)$ & $26(29.5)$ & $87(28.3)$ & $66(30.0)$ & \\
\hline \multicolumn{6}{|l|}{ Stage } \\
\hline I and II & $320(52.0)$ & $39(44.3)$ & $|6|(52.4)$ & $120(54.5)$ & 0.262 \\
\hline III and IV & $295(48.0)$ & $49(55.7)$ & $146(47.6)$ & $100(45.5)$ & \\
\hline \multicolumn{6}{|l|}{ Treatment } \\
\hline $\mathrm{CHO}+\mathrm{RAD}$ & $36(5.8)$ & $3(3.4)$ & $20(6.5)$ & $13(5.9)$ & 0.003 \\
\hline Surgery only & $324(52.7)$ & $38(43.2)$ & $149(48.5)$ & $137(62.3)$ & \\
\hline $\mathrm{SUR}+\mathrm{CHO}+\mathrm{RAD}$ & $255(41.5)$ & $47(53.4)$ & $138(45.0)$ & $70(31.8)$ & \\
\hline
\end{tabular}

Note: Bold values indicate significant differences $(p<0.05)$.

Abbreviations: BMI, body mass index; CHO+RAD, chemotherapy and radiotherapy; SUR+CHO+RAD:, surgery and chemotherapy and radiotherapy; ESCC, esophageal squamous cell carcinoma. 
Table 2 Relationship between the BMI loss and the clinical characteristics in 615 patients with esophageal cancer

\begin{tabular}{|c|c|c|c|c|c|}
\hline \multirow[t]{2}{*}{ Characteristics } & \multirow[t]{2}{*}{ Overall $(n=6 \mid 5)$} & \multicolumn{3}{|l|}{ BMI loss } & \multirow[t]{2}{*}{$p$-value } \\
\hline & & $0(\%)(n=365)$ & $\leq 2(\%)(n=207)$ & $>2(\%)(n=43)$ & \\
\hline $\begin{array}{l}\text { Histopathology } \\
\text { ESCC } \\
\text { Non-ESCC } \\
\text { Small cell carcinoma } \\
\text { Adenocarcinoma }\end{array}$ & $\begin{array}{l}446(72.5) \\
169(27.5) \\
63(37.3) \\
46(27.2)\end{array}$ & $\begin{array}{l}266(72.9) \\
99(27.1) \\
36(36.4) \\
30(30.3)\end{array}$ & $\begin{array}{l}15 \mid(72.9) \\
56(27.1) \\
24(42.9) \\
14(25.0)\end{array}$ & $\begin{array}{l}29(67.4) \\
14(32.6) \\
3(21.4) \\
2(14.3)\end{array}$ & $\begin{array}{l}0.741 \\
0.689\end{array}$ \\
\hline $\begin{array}{l}\text { Gender } \\
\text { Male } \\
\text { Female }\end{array}$ & $\begin{array}{l}474(77.1) \\
|4|(22.9)\end{array}$ & $\begin{array}{l}279(76.4) \\
86(23.6)\end{array}$ & $\begin{array}{l}162(78.3) \\
45(21.7)\end{array}$ & $\begin{array}{l}33(76.7) \\
10(23.3)\end{array}$ & 0.882 \\
\hline $\begin{array}{l}\text { Age } \\
\leq 59 \text { years } \\
>59 \text { years }\end{array}$ & $\begin{array}{l}314(51.1) \\
301(48.9)\end{array}$ & $\begin{array}{l}170(47.8) \\
186(52.2)\end{array}$ & $\begin{array}{l}\text { II2(54.I) } \\
95(45.9)\end{array}$ & $\begin{array}{l}23(50.3) \\
20(49.7)\end{array}$ & 0.317 \\
\hline $\begin{array}{l}\text { Alcohol } \\
\text { Never } \\
\text { Ever }\end{array}$ & $\begin{array}{l}375(62.0) \\
240(38.0)\end{array}$ & $\begin{array}{l}230(63.0) \\
135(37.0)\end{array}$ & $\begin{array}{l}124(59.9) \\
83(40.1)\end{array}$ & $\begin{array}{l}21(61.0) \\
22(39.0)\end{array}$ & 0.183 \\
\hline $\begin{array}{l}\text { Smoking } \\
\text { Never } \\
\text { Ever }\end{array}$ & $\begin{array}{l}217(35.3) \\
398(64.7)\end{array}$ & $\begin{array}{l}136(37.3) \\
229(62.7)\end{array}$ & $\begin{array}{l}67(32.4) \\
140(67.6)\end{array}$ & $\begin{array}{l}14(35.3) \\
29(64.7)\end{array}$ & 0.464 \\
\hline $\begin{array}{l}\text { Diabetes mellitus } \\
\text { No } \\
\text { Yes }\end{array}$ & $\begin{array}{l}587(95.4) \\
28(4.6)\end{array}$ & $\begin{array}{l}348(95.3) \\
17(4.7)\end{array}$ & $\begin{array}{l}197(95.2) \\
10(4.8)\end{array}$ & $\begin{array}{l}42(95.4) \\
I(4.6)\end{array}$ & 0.765 \\
\hline $\begin{array}{l}\text { Hypertension } \\
\text { No } \\
\text { Yes }\end{array}$ & $\begin{array}{l}453(73.7) \\
162(26.3)\end{array}$ & $\begin{array}{l}266(72.9) \\
99(27.1)\end{array}$ & $\begin{array}{l}151(72.9) \\
56(27.1)\end{array}$ & $\begin{array}{l}36(83.7) \\
7(16.3)\end{array}$ & 0.299 \\
\hline $\begin{array}{l}\text { Anemia } \\
\text { No } \\
\text { Yes }\end{array}$ & $\begin{array}{l}548(89.1) \\
67(11.9)\end{array}$ & $\begin{array}{l}333(91.2) \\
32(8.8)\end{array}$ & $\begin{array}{l}184(88.9) \\
23(11.1)\end{array}$ & $\begin{array}{l}3 \mid(72.1) \\
12(27.9)\end{array}$ & 0.001 \\
\hline $\begin{array}{l}\text { Family history } \\
\text { No } \\
\text { Yes }\end{array}$ & $\begin{array}{l}499(81.1) \\
116(19.9)\end{array}$ & $\begin{array}{l}291(79.7) \\
74(20.3)\end{array}$ & $\begin{array}{l}169(81.6) \\
38(18.4)\end{array}$ & $\begin{array}{l}39(90.7) \\
4(9.3)\end{array}$ & 0.215 \\
\hline $\begin{array}{l}\text { Location } \\
\text { Up } \\
\text { Middle } \\
\text { Low }\end{array}$ & $\begin{array}{l}56(9.1) \\
380(61.8) \\
179(29.1)\end{array}$ & $\begin{array}{l}32(8.8) \\
235(64.4) \\
98(26.8)\end{array}$ & $\begin{array}{l}21(10.1) \\
121(58.5) \\
65(31.4)\end{array}$ & $\begin{array}{l}3(7.0) \\
24(55.8) \\
16(37.2)\end{array}$ & 0.477 \\
\hline $\begin{array}{l}\text { Stage } \\
\text { I and II } \\
\text { III and IV }\end{array}$ & $\begin{array}{l}320(52.0) \\
295(48.0)\end{array}$ & $\begin{array}{l}208(57.0) \\
157(43.0)\end{array}$ & $\begin{array}{l}92(44.4) \\
115(55.6)\end{array}$ & $\begin{array}{l}20(52.0) \\
23(48.0)\end{array}$ & 0.012 \\
\hline $\begin{array}{l}\text { Treatment } \\
\text { CHO+RAD } \\
\text { Surgery only } \\
\text { SUR+CHO+RAD }\end{array}$ & $\begin{array}{l}36(5.8) \\
324(52.7) \\
255(41.5)\end{array}$ & $\begin{array}{l}16(1.7) \\
200(56.3) \\
149(42.0)\end{array}$ & $\begin{array}{l}15(7.2) \\
99(47.8) \\
93(44.9)\end{array}$ & $\begin{array}{l}5(11.6) \\
25(58.1) \\
13(30.2)\end{array}$ & 0.001 \\
\hline
\end{tabular}

Note: Bold values indicate significant differences $(p<0.05)$.

Abbreviations: $B M I$, body mass index; $C H O+R A D$, chemotherapy and radiotherapy; SUR+CHO+RAD, surgery and chemotherapy and radiotherapy; ESCC, esophageal squamous cell carcinoma. 
Table 3 Overall survival analysis in 615 patients with esophageal cancer

\begin{tabular}{|c|c|c|c|c|}
\hline \multirow[t]{2}{*}{ Variables } & \multicolumn{4}{|c|}{ Overall survival (OS) } \\
\hline & Mean & Median & 5 year OS(\%) & 10 year OS(\%) \\
\hline \multicolumn{5}{|l|}{ Histopathology } \\
\hline ESCC & 68.1 & 47.0 & 46.0 & 39.2 \\
\hline Non-ESCC & 52.9 & 21.0 & 43.8 & 39.1 \\
\hline Small cell carcinoma & 32.7 & 17.0 & 36.5 & 34.9 \\
\hline Adenocarcinoma & 59.3 & 33.0 & 47.8 & 43.5 \\
\hline \multicolumn{5}{|l|}{ Gender } \\
\hline Male & 69.3 & 39.0 & 45.8 & 40.5 \\
\hline Female & 63.0 & 28.0 & 39.7 & 34.8 \\
\hline \multicolumn{5}{|l|}{ Age (years) } \\
\hline$\leq 59$ & 70.0 & 37.0 & 44.9 & 41.7 \\
\hline$>59$ & 60.8 & 37.0 & 43.9 & 36.5 \\
\hline \multicolumn{5}{|l|}{ TNM stage $\#$} \\
\hline I-II & 89.0 & 60.0 & 59.4 & 54.1 \\
\hline III-IV & 44.4 & 19.0 & 28.1 & 23.1 \\
\hline \multicolumn{5}{|l|}{ Alcohol } \\
\hline Never & 71.2 & 43.0 & 46.4 & 41.9 \\
\hline Ever & 58.5 & 31.0 & 41.3 & 35.0 \\
\hline \multicolumn{5}{|l|}{ Smoking } \\
\hline Never & 1.7 & 44.0 & 46.5 & 42.4 \\
\hline Ever & 65.7 & 34.0 & 43.3 & 37.4 \\
\hline \multicolumn{5}{|l|}{ Diabetes mellitus } \\
\hline No & 67.5 & 37.0 & 44.0 & 39.0 \\
\hline Yes & 67.1 & 69.0 & 53.6 & 42.9 \\
\hline \multicolumn{5}{|l|}{ Hypertension } \\
\hline No & 66.6 & 37.0 & 43.9 & 38.9 \\
\hline Yes & 66.5 & 37.0 & 45.7 & 40.1 \\
\hline \multicolumn{5}{|l|}{ Anemia } \\
\hline No & 69.6 & 38.0 & 45.3 & 40.7 \\
\hline Yes & 50.0 & 27.0 & 37.3 & 26.9 \\
\hline \multicolumn{5}{|l|}{ BMI loss } \\
\hline No & 74.4 & 50.0 & 50.1 & 43.6 \\
\hline Yes & 54.3 & 28.0 & 36.0 & 32.8 \\
\hline \multicolumn{5}{|l|}{ Treatment } \\
\hline $\mathrm{CHO}+\mathrm{RAD}$ & 46.3 & 19.0 & 38.9 & 38.9 \\
\hline Surgery only & 69.4 & 39.0 & 44.8 & 41.0 \\
\hline$S U R+C H O+R A D$ & 6.6 & 39.0 & 44.7 & 36.9 \\
\hline \multicolumn{5}{|l|}{ BMI status } \\
\hline$<18.5 \mathrm{~kg} / \mathrm{m}^{2}$ & 52.5 & 26.0 & 33.0 & 29.5 \\
\hline $18.5-22.9 \mathrm{~kg} / \mathrm{m}^{2}$ & 65.0 & 33.0 & 43.0 & 36.2 \\
\hline$\geq 23.0 \mathrm{~kg} / \mathrm{m}^{2}$ & 77.3 & 51.0 & 50.5 & 47.3 \\
\hline
\end{tabular}

Notes: \#TNM denotes tumor-node-metastasis.

Abbreviations: $\mathrm{CHO}+\mathrm{RAD}$, chemotherapy and radiotherapy; SUR+CHO+RAD, Surgery and chemotherapy and radiotherapy; ESCC, esophageal squamous cell carcinoma. 
value of BMI and BMI loss in esophageal cancer patients, the demographic data, clinicopathological features, life style, BMI, and BMI loss were evaluated using univariate and multivariate Cox regression models (Table 4). The univariate analysis revealed that histopathology, TNM stage, anemia, BMI, and BMI loss were significantly associated with the survival of esophageal cancer patients. However, gender, age, alcohol history, smoking history, diabetes mellitus, high blood pressure, and treatment were not significantly associated. Thus, the significant variables were selected for multivariate analysis using the enter method. The multivariate analysis showed that histopathology ( $\mathrm{HR}=1.545$; 95\%CI: 1.227-1.946; $p<0.001)$, TNM stage $(\mathrm{HR}=2.533 ; 95 \% \mathrm{CI}: 2.050-3.131 ; p<0.001)$, and $\mathrm{BMI}$ $(\mathrm{HR}=0.829 ; 95 \% \mathrm{CI}: 0.711-0.966 ; p=0.017)$ were independent prognostic indicators of esophageal cancer survival. What's more, when we model BMI and BMI loss as continuous predictors, it shows that for every 1 unit increased in BMI and BMI loss, the HR decreased to $0.952(0.921-0.984)(p=0.004)$ and increased to $1.039(1.004-1.076)(p=0.030)$. Thus, these findings suggest that BMI prior to therapy may serve as a novel independent prognostic factor for esophageal cancer.

Table 4 Multivariate Cox hazards analysis for OS in 615 patients with esophageal cancer

\begin{tabular}{|c|c|c|}
\hline & Multivariate sur & analysis \\
\hline Variables & $\mathrm{HR}(95 \% \mathrm{Cl})$ & $p$-value* \\
\hline $\begin{array}{l}\text { Histopathology } \\
\text { ESCC } \\
\text { Non-ESCC }\end{array}$ & $1.523(1.209-1.918)$ & 0.000 \\
\hline $\begin{array}{l}\text { TNM stage \# } \\
\text { I-II } \\
\text { III-IV }\end{array}$ & $2.533(2.050-3.131)$ & 0.000 \\
\hline $\begin{array}{l}\text { Anemia } \\
\text { No } \\
\text { Yes }\end{array}$ & $1.262(0.929-1.713)$ & 0.137 \\
\hline $\begin{array}{l}\text { BMI loss } \\
\text { No } \\
\text { Yes } \\
\text { As continuous variables }\end{array}$ & $\begin{array}{l}1.194(0.970-1.469) \\
1.039(1.004-1.076)\end{array}$ & 0.030 \\
\hline $\begin{array}{l}\text { BMI status } \\
<18.5 \mathrm{~kg} / \mathrm{m}^{2} \\
18.5-22.9 \mathrm{~kg} / \mathrm{m}^{2} \\
\geq 23.0 \mathrm{~kg} / \mathrm{m}^{2} \\
\text { As continuous variables }\end{array}$ & $0.952(0.921-0.984)$ & 0.004 \\
\hline
\end{tabular}

Notes: Bold values indicate significant differences $(p<0.05)$. ${ }^{*}$ Cox hazard regression model. "TNM denotes tumor-node-metastasis.

Abbreviations: BMI, body mass index; ESCC, esophageal squamous cell carcinoma; OS, overall survival.

\section{Prognostic significance of BMI}

To further explore the prognostic significance of BMI in esophageal cancer patients, Kaplan-Meier survival curves were generated, and the groups were compared using the logrank test. The patients were categorized into the following three groups: the underweight group $\left(<18.5 \mathrm{~kg} / \mathrm{m}^{2}\right)$, the normal weight group $\left(18.5-22.9 \mathrm{~kg} / \mathrm{m}^{2}\right)$, and the overweight and obese group $\left(\geq 23.0 \mathrm{~kg} / \mathrm{m}^{2}\right)$. In the entire cohort, overweight and obese patients had significantly better 10 year OS than underweight and normal weight patients (Figure 1). The cumulative 10 year survival rate in the overweight and obese group was $47.3 \%$, whereas it was only $29.5 \%$ and $36.2 \%$ in the underweight and normal weight groups, respectively. Additionally, patients were categorized into either an ESCC group or a non-ESCC group to evaluate the 10 year OS differences according to the BMI index. This is because the 10 year survival rates in these two groups were different $(p<0.001$, Figure 2A). The 10 year OS in patients with a high BMI was significantly longer than patients with a low BMI in both the whole cohort $(p=0.004$, Figure 1$)$ and the ESCC cohort $(p=0.003$, Figure $2 \mathrm{~B})$. However, there was no significant difference in 10 year OS among the three BMI groups in the non-ESCC group $(P=0.667$, Figure $2 \mathrm{C})$.

\section{Combining the prognostic significance of $\mathrm{BMI}$ and BMI loss}

To further explore the prognostic significance of combining BMI and BMI loss, we generated Kaplan-Meier survival curves and performed the log-rank test for the whole cohort. The prognostic significance is shown in Figure S1. Patients were divided into six groups: group 1 (BMI $<18.5 \mathrm{~kg} / \mathrm{m}^{2}$ and BMI loss $=0)$, group $2\left(18.5 \leq \mathrm{BMI}<23.0 \mathrm{~kg} / \mathrm{m}^{2}\right.$ and BMI loss $=0$ ), group $3\left(\mathrm{BMI} \geq 23.0 \mathrm{~kg} / \mathrm{m}^{2}\right.$ and BMI loss $\left.=0\right)$, group 4 (BMI $<18.5 \mathrm{~kg} / \mathrm{m}^{2}$ and BMI loss $>0$ ), group 5 $\left(18.5 \leq\right.$ BMI $<23.0 \mathrm{~kg} / \mathrm{m}^{2}$ and BMI loss $\left.>0\right)$, group 6 (BMI $\geq 23.0 \mathrm{~kg} / \mathrm{m}^{2}$ and BMI loss $>0$ ). The 10 year OS rates of the six groups were significantly different $(p=0.001)$. Patients with a high BMI and no BMI loss (group 3) had a significantly higher survival probability than the other five groups. Conversely, the survival rate of underweight patients with BMI loss (group 4) was the lowest among the six groups. The order of the survival rates of the six groups from high to low was as follows: group $3(51.0 \%)>$ group 6 $(40.0 \%)>$ group $2(39.2 \%)>$ group $1(36.4 \%)>$ group 5 $(32.1 \%)>$ group $4(22.7 \%)$ (Figure S1B). Although BMI loss was not an independent prognostic factor for esophageal cancer $(\mathrm{HR}=1.194,95 \%$ CI: $0.970-1.469, P=0.095)$, there was 


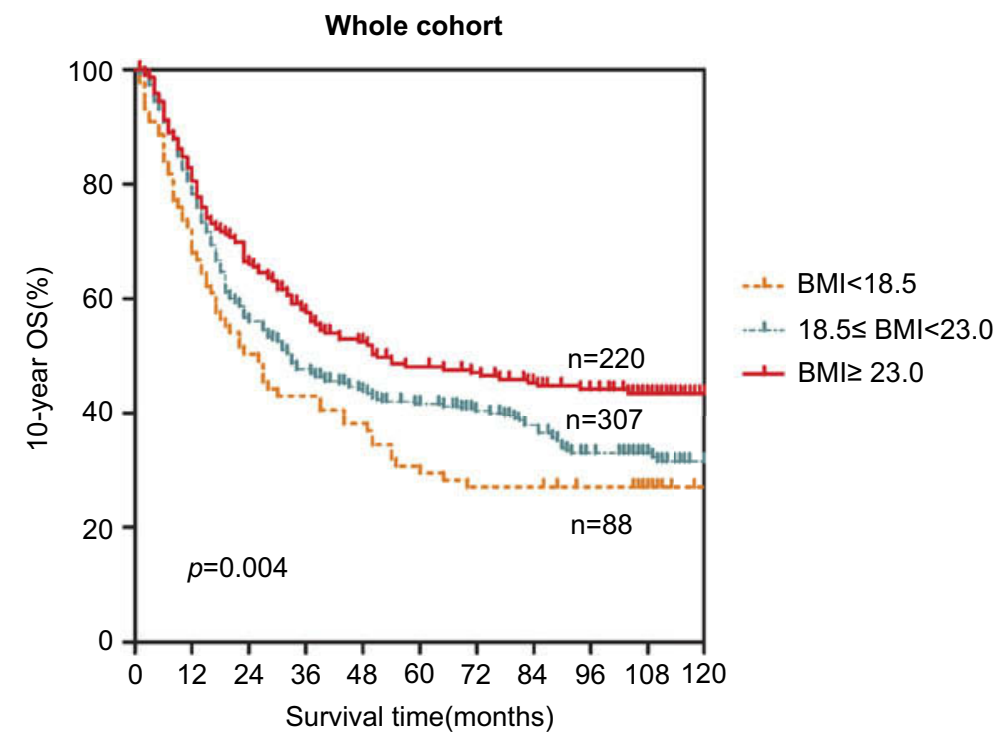

Figure I Prognostic significance of BMI in 615 esophageal cancer patients. The 10 year overall survival rate was calculated using the Kaplan-Meier method and analyzed with the log-rank test. The patients were categorized into a low BMI group, normal BMI group and a high BMI group, according to the Asian-specific BMI cutoff. A high BMI level was a favorable prognostic factor in whole esophageal cancer patients cohort.

Abbreviation: BMI, body mass index.
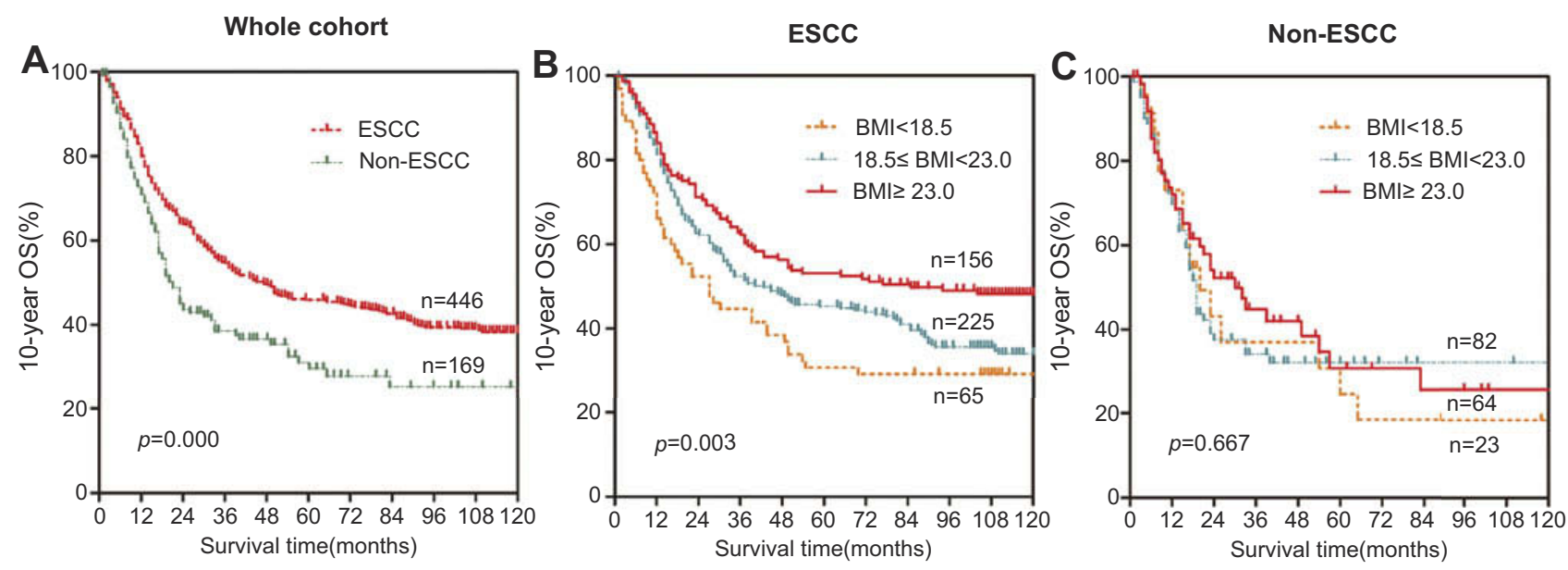

Figure 2 Prognostic significance of BMI in ESCC and non-ESCC groups. The overall survival rate was calculated using the Kaplan-Meier method and analyzed with the logrank test. The patients were categorized into either the ESCC group or the non-ESCC group. (A) The 10 year overall survival rate was different in these two groups. (B) A high BMI was a favorable prognostic factor in the ESCC group. (C) There were no statistically significant differences in the non-ESCC group.

Abbreviations: BMI, body mass index; ESCC, esophageal squamous cell carcinoma.

a significant difference $(p<0.001)$ in the 10 year OS among the three BMI loss groups in the whole cohort (Figure S1A). To further explore the changes related to BMI loss, we calculated the mortality rate (Figure S1C). The results indicate that the mortality rate increased as BMI loss increased.

\section{Discussion}

Our study demonstrates that pretreatment BMI could be an independent prognostic factor for long-term OS in esophageal cancer patients. We found that the 10 year OS of patients with a high BMI were significantly longer than patients with a low BMI, which was true for both the entire cohort and the ESCC group. This result was consistent with previous studies in both benign tumors ${ }^{22-25}$ and malignant tumors. ${ }^{12,26-33}$ Although there have been studies that investigated the relationship between esophageal cancer and BMI, ${ }^{12,16,34-39}$ these studies primarily focused on operative squamous cell carcinoma, esophageal adenocarcinoma, or patients only treated with adjuvant therapy. Moreover, a population study of esophageal cancer patients treated with different therapies, including surgery and 
adjuvant therapy, has not been explored. In other words, there are no reports of clinical research on the relationship between pretreatment BMI and esophageal cancer patients treated with adjuvant therapy in the Chinese population.

Although BMI levels were different in different studies, the results of this study were consistent with other studies on the prognosis of esophageal cancer. ${ }^{12,37,40}$ The reason why overweight and obese patients might have improved survival is not clear. Previous studies have indicated that the prognostic advantage for overweight and obese patients might be attributed to the fact that overweight and obese patients were more likely to never have smoked, never have consumed alcohol, and not have lost weight before surgery. ${ }^{16,41}$ In our study, patients with a high BMI were less likely to be smokers $(p=0.007)$. Moreover, it was previously reported that pre-operative malnutrition was associated with poor survival in cancer patients. ${ }^{42}$ Overweight and obese patients might have a better nutritional reserve to resist cancer. ${ }^{43}$ In this study, patients with a high BMI were less likely to be anemic $(p<0.001)$, and this may imply better physical conditions.

As a calculation that indicates body fat, BMI is different from other unchangeable factors, such as age, race, and gender. It is potentially more modifiable. The factor that affects body weight may be a factor that influences the relationship between BMI and the prognosis of esophageal cancer patients. Weight loss is a common presenting symptom of digestive system neoplasms, especially in oral cancer, esophageal cancer, and gastric carcinoma. This is because most patients will experience dysphagia and odynophagia, which lead to reduced food intake. Also contributing to weight loss and malnutrition is the increased energy consumption and altered nutrient metabolism that is associated with systemic inflammation, which can be induced by the tumor. ${ }^{5,6,44}$ This is especially true for esophageal cancer patients after surgery. ${ }^{45,46}$ It is known that significant weight loss in cancer patients is a risk factor for longterm survival. Several studies have reported that preoperative weight loss $>10 \%$ of body weight can increase the risk of mortality after surgery by more than $10 \%$ in esophageal cancer patients. ${ }^{13,20,21}$ In this study, we chose BMI loss instead of weight loss to evaluate the influence of weigh change on survival by taking patient height into consideration. The Hazard Ratios (HRs) of BMI loss suggest that pretreatment BMI loss increased mortality, although this was not statistically significant (HR $=1.194 ; 95 \%$ CI: 0.970-1.469; $p=0.095)$. However, the mortality rate of patients in the present cohort increased as BMI loss increased. BMI loss was closely related to the cancer stage; a higher BMI loss had higher $\mathrm{T}(p=0.007)$ classifications.

Nevertheless, we should acknowledge that the association between BMI and survival might be influenced by certain significant confounding factors. Studies have shown that a higher household income was associated with a $33-38 \%$ decrease in risk of death in esophageal cancer. ${ }^{40}$ Thus, improving the general socioeconomic status is a promising approach for reducing the tremendous burden of upper gastrointestinal cancers. ${ }^{38}$ In other words, patients with good socioeconomic status, income status, and education were more likely to receive better treatment because of better health consciousness and financial support.

However, this is a single-center retrospective analysis, and we need to validate the key findings and conclusions with other commonly used validation methods, including an independent cohort, in the future.

\section{Conclusion}

Our study provides more concrete evidence that a high BMI is associated with favorable long-term survival in esophageal cancer patients treated with different therapies in China. Patients with a low BMI and high BMI loss before therapy had a worse outcome than other patients with esophageal cancer. These results emphasize that the nutritional status in malnourished patients with esophageal cancer should be improved before therapy for a better prognosis.

\section{Acknowledgments}

We thank the staff at the Director of Clinical Laboratories, Sun Yat-Sen Memorial Hospital, and Sun Yat-sen University Cancer Center for providing support on research conditions in this study. This work was supported by the National Natural Science Foundation of China (NSFC, No. 31170147), the Guangdong Natural Science Foundation (Grant Numbers: S2013010014007 and 2014A030313070) and the Guangdong Province Science and Technology Project Plan and Social Development Foundation (2010A030400006).

\section{Disclosure}

The authors report no conflicts of interest in this work. 


\section{References}

1. Arnold M, Soerjomataram I, Ferlay J, Forman D. Global incidence of oesophageal cancer by histological subtype in 2012. Gut. 2015;64 (3):381-387. doi:10.1136/gutjnl-2014-308124

2. Jemal A, Bray F, Center MM, Ferlay J, Ward E, Forman D. Global cancer statistics. CA Cancer J Clin. 2011;61(2):69-90. doi:10.3322 caac. 20107

3. Lin Y, Totsuka Y, He Y, et al. Epidemiology of esophageal cancer in Japan and China. J Epidemiol. 2013;23(4):233-242.

4. Siegel RL, Miller KD, Jemal A. Cancer statistics. CA Cancer J Clin. 2016;66(1):7-30. doi:10.3322/caac. 21332

5. Daly JM, Fry WA, Little AG, et al. Esophageal cancer: results of an American College of Surgeons patient care evaluation study. $J \mathrm{Am}$ Coll Surg. 2000;190(5):562-572, discussion 572-563.

6. Deans DA, Tan BH, Wigmore SJ, et al. The influence of systemic inflammation, dietary intake and stage of disease on rate of weight loss in patients with gastro-oesophageal cancer. $\mathrm{Br} J$ Cancer. 2009;100(1):63-69. doi:10.1038/sj.bjc.6604828

7. Djarv T, Lagergren P. Quality of life after esophagectomy for cancer. Expert Rev Gastroenterol Hepatol. 2012;6(1):115-122. doi:10.1586/ egh.11.91

8. Martin L, Lagergren P. Long-term weight change after oesophageal cancer surgery. Br J Surg. 2009;96(11):1308-1314. doi:10.1002/bjs.6723

9. Aoyama T, Sato T, Maezawa Y, et al. Postoperative weight loss leads to poor survival through poor S-1 efficacy in patients with stage II/III gastric cancer. Int J Clin Oncol. 2017;22(3):476-483. doi:10.1007/ s10147-017-1089-y

10. Cespedes FEM, Kroenke CH, Bradshaw PT, et al. Postdiagnosis weight change and survival following a diagnosis of early-stage breast cancer. Cancer Epidemiol Biomarkers Prev. 2017;26 (1):44-50. doi:10.1158/1055-9965.EPI-16-0150

11. Meyerht JA, Kroenke CH, Prado CM, et al. Association of weight change after colorectal cancer diagnosis and outcomes in the Kaiser Permanente Northern California population. Cancer Epidemiol Biomarkers Prev. 2017;26(1):30-37. doi:10.1158/1055-9965.EPI-16-0145

12. Hynes O, Anandavadivelan P, Gossage J, Johar AM, Lagergren J, Lagergren $\mathrm{P}$. The impact of pre- and post-operative weight loss and body mass index on prognosis in patients with oesophageal cancer. Eur J Surg Oncol. 2017;43(8):1559-1565. doi:10.1016/j.ejso.2017.05.023

13. van der Schaaf MK, Tilanus HW, van Lanschot JJ, et al. The influence of preoperative weight loss on the postoperative course after esophageal cancer resection. J Thorac Cardiovasc Surg. 2014;147 (1):490-495. doi:10.1016/j.jtcvs.2013.07.072

14. Hoyo C, Cook MB, Kamangar F, et al. Body mass index in relation to oesophageal and oesophagogastric junction adenocarcinomas: a pooled analysis from the International BEACON Consortium. Int J Epidemiol. 2012;41(6):1706-1718. doi:10.1093/ije/dys 176

15. Lagergren J. Influence of obesity on the risk of esophageal disorders. Nat Rev Gastroenterol Hepatol. 2011;8(6):340-347. doi:10.1038/ nrgastro.2011.73

16. Zhang SS, Yang H, Luo KJ, et al. The impact of body mass index on complication and survival in resected oesophageal cancer: a clinical-based cohort and meta-analysis. Br J Cancer. 2013;109 (11):2894-2903. doi:10.1038/bjc.2013.666

17. Li XH, Gu WS, Wang XP, et al. Low preoperative albumin-toglobulin ratio predict poor survival and negatively correlated with fibrinogen in resectable esophageal squamous cell carcinoma. $J$ Cancer. 2017;8(10):1833-1842. doi:10.7150/jca.19062

18. Rice TW, Blackstone EH, Rusch VW. 7th edition of the AJCC Cancer Staging Manual: esophagus and esophagogastric junction. Ann Surg Oncol. 2010;17(7):1721-1724. doi:10.1245/s10434-010-1024-1

19. Steering Committee of the Western Pacific Region of the World Health Organization TIAF. The Asia-Pacific Perspective: Redefining Obesity and its Treatment. Melbourne (Australia): Health Communications Australia Pty Limited; 2000.
20. Mal F, Perniceni T, Levard H, Denet C, Validire P, Gayet B. Preoperative predictive factors of early recurrence after resection of adenocarcinoma of the esophagus and cardia. Gastroenterol Clin Biol. 2005;29(12):1275-1278.

21. Stahl M, Wilke H, Stuschke M, et al. Clinical response to induction chemotherapy predicts local control and long-term survival in multimodal treatment of patients with locally advanced esophageal cancer. J Cancer Res Clin Oncol. 2005;131(1):67-72. doi:10.1007/s00432-004-0604-5

22. Cook MB, Greenwood DC, Hardie LJ, Forman D, Wild CP. On the association between body mass index and Barrett's esophagus. Ann Thorac Surg. 2009;88(5):1728. doi:10.1016/j.athoracsur.2009.04.142

23. Corley DA, Kubo A, Levin TR, et al. Abdominal obesity and body mass index as risk factors for Barrett's esophagus. Gastroenterology. 2007;133(1):34-41. quiz 311. doi:10.1053/j.gastro.2007.04.046

24. Kamat P, Wen S, Morris J, Anandasabapathy S. Exploring the association between elevated body mass index and Barrett's esophagus: a systematic review and meta-analysis. Ann Thorac Surg. 2009;87 (2):655-662. doi:10.1016/j.athoracsur.2008.08.003

25. Nathanson BH, Navab F. An analysis of weight gains and body mass index in patients with Barrett's esophagus. J Acad Nutr Diet. 2016;116(7):1156-1162. doi:10.1016/j.jand.2016.03.009

26. Bell S, Kong JC, Wale R, et al. The effect of increasing body mass index on laparoscopic surgery for colon and rectal cancer. Colorectal Dis. 2018. doi:10.1111/codi.14107

27. Cho WK, Choi DH, Park W, et al. Effect of body mass index on survival in breast cancer patients according to subtype, metabolic syndrome, and treatment. Clin Breast Cancer. 2018. doi:10.1016/j.clbc.2018.04.010

28. Cong Z, Wang D, Cao Y. The relationship between body mass index changes during chemotherapy and prognosis of patients with advanced colorectal cancer: a retrospective cohort study. Medicine (Baltimore). 2018;97(22):e10843. doi:10.1097/MD.0000000000010843

29. Desmedt C, Demicheli R, Fornili M, et al. Potential benefit of intraoperative administration of ketorolac on breast cancer recurrence according to the patient's body mass index. $J$ Natl Cancer Inst. 2018. doi:10.1093/jnci/djy042

30. Fang X, Wei J, He X, et al. Quantitative association between body mass index and the risk of cancer: a global meta-analysis of prospective cohort studies. Int $J$ Cancer. 2018. doi:10.1002/ijc.31553

31. Okura T, Fujii M, Shiode J, et al. Impact of body mass index on survival of pancreatic cancer patients in Japan. Acta Med Okayama. 2018;72(2):129-135. doi:10.18926/AMO/55853

32. Wang C, Guo M, Zhang N, Wang G. Association of body mass index and outcomes following lobectomy for non-small-cell lung cancer. World J Surg Oncol. 2018;16(1):90. doi:10.1186/s12957-018-1394-6

33. Zhang J, Chen Q, Li ZM, Xu XD, Song AF, Wang LS. Association of body mass index with mortality and postoperative survival in renal cell cancer patients, a meta-analysis. Oncotarget. 2018;9 (17):13959-13970. doi:10.18632/oncotarget.24210

34. Kubo A, Corley DA. Body mass index and adenocarcinomas of the esophagus or gastric cardia: a systematic review and meta-analysis. Cancer Epidemiol Biomarkers Prev. 2006;15(5):872-878. doi:10.1158/ 1055-9965.EPI-05-0860

35. Li SD, Mobarhan S. Association between body mass index and adenocarcinoma of the esophagus and gastric cardia. Nutr Rev. 2000;58(2 Pt 1):54-56.

36. Shinkai H, Iijima K, Koike T, et al. Association between the body mass index and the risk of Barrett's esophagus in Japan. Digestion. 2014;90(1):1-9. doi:10.1159/000357776

37. Smith M, Zhou M, Whitlock G, et al. Esophageal cancer and body mass index: results from a prospective study of 220,000 men in China and a meta-analysis of published studies. Int $J$ Cancer. 2008;122 (7):1604-1610. doi:10.1002/ijc.23198

38. Tran GD, Sun XD, Abnet CC, et al. Prospective study of risk factors for esophageal and gastric cancers in the Linxian general population trial cohort in China. Int $J$ Cancer. 2005;113(3):456-463. doi:10.1002/ijc.20616 
39. Watanabe M, Ishimoto T, Baba Y, et al. Prognostic impact of body mass index in patients with squamous cell carcinoma of the esophagus. Ann Surg Oncol. 2013;20(12):3984-3991. doi:10.1245/ s10434-013-3073-8

40. Trivers KF, De Roos AJ, Gammon MD, et al. Demographic and lifestyle predictors of survival in patients with esophageal or gastric cancers. Clin Gastroenterol Hepatol. 2005;3(3):225-230.

41. Thrift AP, Nagle CM, Fahey PP, et al. The influence of prediagnostic demographic and lifestyle factors on esophageal squamous cell carcinoma survival. Int J Cancer. 2012;131(5):E759-768. doi:10.1002/ijc.27420

42. Morgan TM, Tang D, Stratton KL, et al. Preoperative nutritional status is an important predictor of survival in patients undergoing surgery for renal cell carcinoma. Eur Urol. 2011;59(6):923-928. doi:10.1016/j.eururo.2011.01.034
43. Davos $\mathrm{CH}$, Doehner W, Rauchhaus $\mathrm{M}$, et al. Body mass and survival in patients with chronic heart failure without cachexia: the importance of obesity. $J$ Card Fail. 2003;9(1):29-35. doi:10.1054/jcaf.2003.4

44. Anandavadivelan P, Lagergren P. Cachexia in patients with oesophageal cancer. Nat Rev Clin Oncol. 2016;13(3):185-198. doi:10.1038/ nrclinonc. 2015.200

45. Martin L, Lagergren J, Lindblad M, Rouvelas I, Lagergren P. Malnutrition after oesophageal cancer surgery in Sweden. $\mathrm{Br}$ J Surg. 2007;94(12):1496-1500. doi:10.1002/bjs.5881

46. Ouattara M, D'Journo XB, Loundou A, et al. Body mass index kinetics and risk factors of malnutrition one year after radical oesophagectomy for cancer. Eur J Cardiothorac Surg. 2012;41 (5):1088-1093. doi:10.1093/ejcts/ezr182 


\section{Supplementary materials}
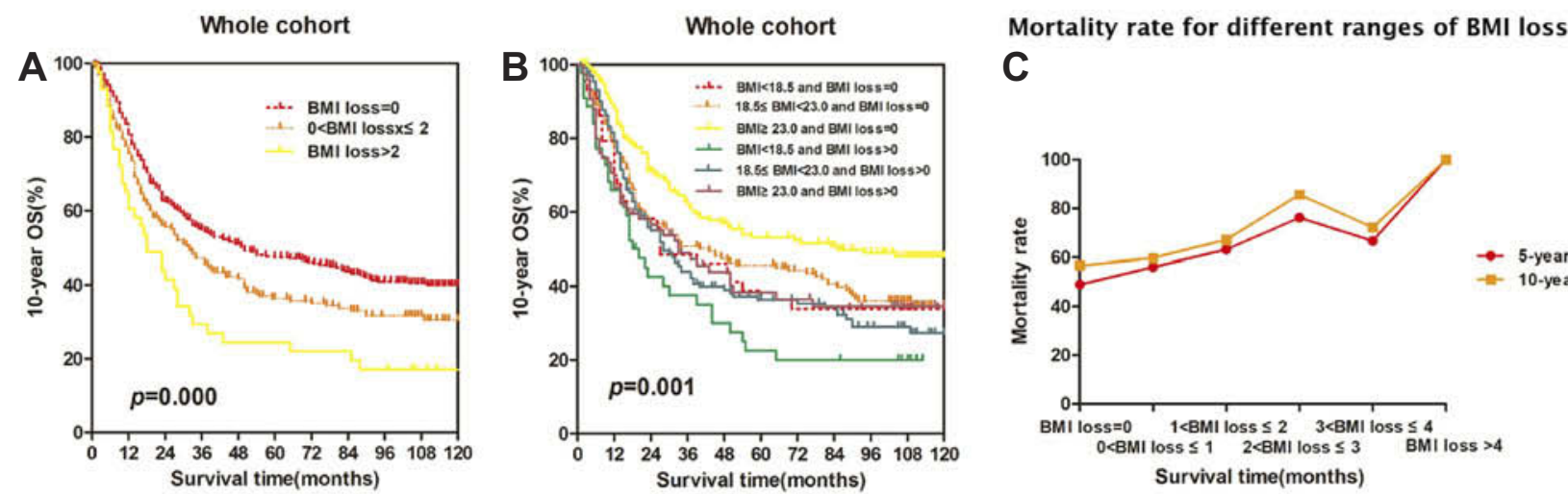

Figure SI Combining the prognostic significance of BMI and BMI loss. The overall survival rate was calculated using the Kaplan-Meier method and analyzed with the logrank test. The patients were categorized into three groups: group I (no BMI loss), group 2 (BMI loss $\leq 2$ ), and group 3 (BMI loss $>2$ ). (A) Patients with no BMI loss had a higher 10 year overall survival rate. (B) Patients with a high BMI and no BMI loss had a significantly higher survival probability than the other groups. (C) The mortality rate increased as BMI loss increased.

Table SI Main cancer type in 169 patients with non-ESCC

\begin{tabular}{|l|l|}
\hline Histopathology & Number (\%) \\
\hline Small cell carcinoma & $63(37.3)$ \\
Adenocarcinoma + adenosquamous carcinoma & $46(27.2)$ \\
Sarcomatoid carcinoma + carcinosarcoma & $31(18.3)$ \\
Neuroendocrine carcinoma & $12(7.1)$ \\
Malignant melanoma & $8(4.7)$ \\
Mesenchymoma & $5(3.0)$ \\
Signet-ring cell carcinoma & $\mathrm{I}(0.6)$ \\
Rhabdomyosarcoma & $\mathrm{I}(0.6)$ \\
Neurinoma & $\mathrm{I}(0.6)$ \\
Mucoepidermoid carcinoma & $\mathrm{I}(0.6)$ \\
\hline
\end{tabular}

Abbreviation: ESCC, esophageal squamous cell carcinoma. 


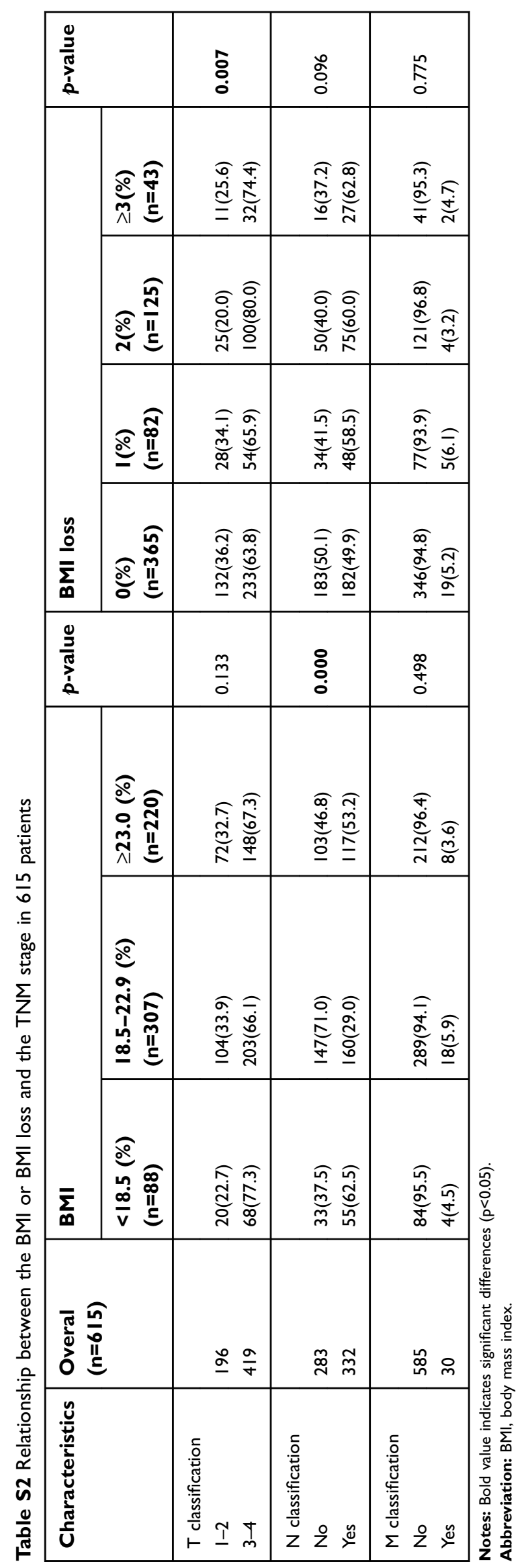




\section{Publish your work in this journal}

Cancer Management and Research is an international, peer-reviewed open access journal focusing on cancer research and the optimal use of preventative and integrated treatment interventions to achieve improved outcomes, enhanced survival and quality of life for the cancer patient.
The manuscript management system is completely online and includes a very quick and fair peer-review system, which is all easy to use. Visit http://www.dovepress.com/testimonials.php to read real quotes from published authors.

Submit your manuscript here: https://www.dovepress.com/cancer-management-and-research-journal 